\title{
Aspects of International Petroleum Agreements
}

\section{DON GREENFIELD AND BOB ROONEY}

The authors consider the inclusion of four types of provisions in international petroleum agreements: frameworks for appraisal determining commerciality, minimum work commitment sections, force majeure clauses and provisions for international dispute resolution. In discussing each of these areas, the authors include sample clauses and consider issues that may impact on the drafting of such clauses, from the point of view of international oil companies and host countries.
Les auteurs envisagent l'inclusion de quatre oypes de dispositions dans les accords pétroliers intermationaux: cadres d'appriciation de la commercialité, clouses relatives d̀ l'engagement d'effectuer un travail minimum, clauses de force majeure et dispositions prévoyant le règlement des différends internationaux. Dans la discussion de chacun de ces domaines, les auteurs incluent des clauses types et examinent des facteurs susceptibles d'influer sur leur formulation - du point de vue des compagnies pettrolières internationales et des pays d'accueil.

\section{TABLE OF CONTENTS}

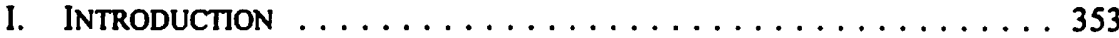

II. APPRAISAL AND COMMERCIALITY $\ldots \ldots \ldots \ldots \ldots \ldots \ldots \ldots 35$

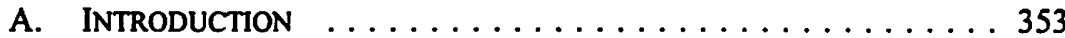

B. OVERview of APPRAISAL Provisions $\ldots \ldots \ldots \ldots \ldots \ldots 353$

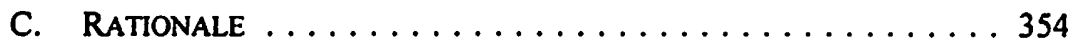

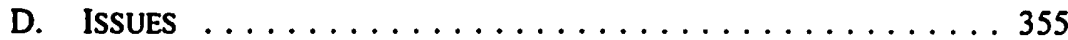

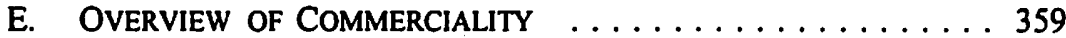

F. Rationale of Commerciality Clauses $\ldots \ldots \ldots \ldots \ldots 360$

G. COMMERCIALITY ISSUES $\ldots \ldots \ldots \ldots \ldots \ldots \ldots \ldots$

H. COMMERCIALIZATION fOR NATURAL GAS $\ldots \ldots \ldots \ldots 363$

III. MINIMUM WORK COMMITMENTS $\ldots \ldots \ldots \ldots \ldots \ldots \ldots 363$

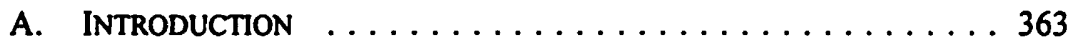

B. COMPONENTS OF TYPICAL MINIMUM WORK Commitment Clauses .................. 364

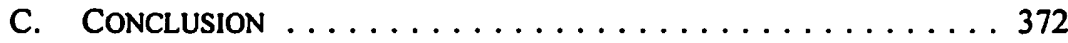

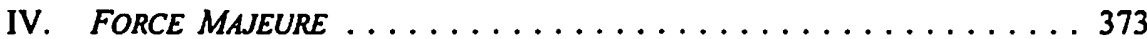

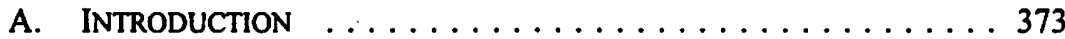

B. REQUIREMENTS FOR FORCE MAJEURE $\ldots \ldots \ldots \ldots \ldots \ldots 373$

C. EVENTS WHICH TRIGGER

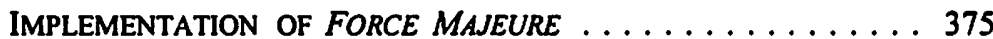

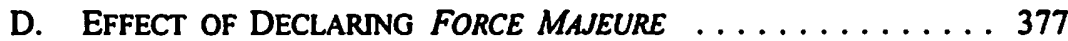

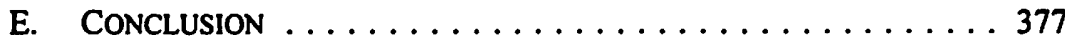

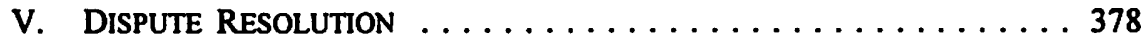

Partners in the Energy Department and the International Energy Practice Team in the Calgary office of Bennett Jones, Barristers and Solicitors. The authors owe a debt of gratitude to Russell Waterson and John Truswell, articling students at Bennett Jones, and Joanne Rowe and Michael Johnson, summer law clerks at the authors' firm, for their research and writing assistance. The authors also acknowledge the contributions of James McHugh, senior legal counsel at Amoco Corporation in Houston, and Frank Alexander, an independent international law practitioner in Houston; the authors have drawn from the papers they prepared for the London conference in March 1998 on force majeure and dispute resolution in the preparation of this article. 


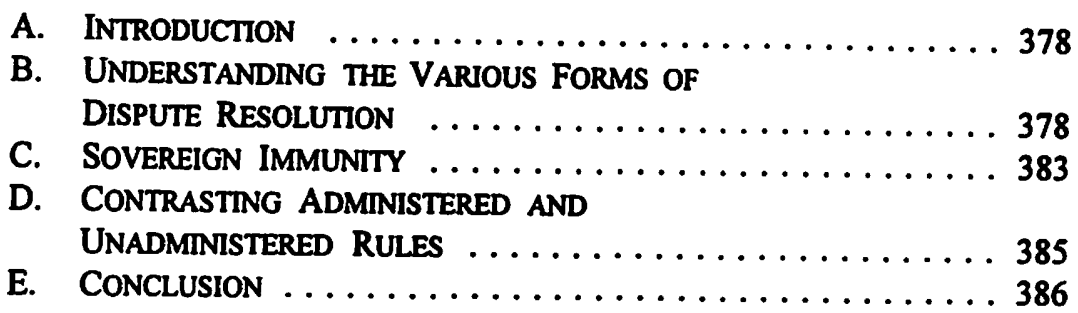

\section{INTRODUCTION}

The purpose of this article is to identify and address four main issues in international petroleum agreements ("IPAs"), i.e., agreements such as exploration and production sharing agreements (an "EPSA"), association contracts and concessions. These issues are the definition and requirements for appraisal work and commerciality, the issues arising around minimum work commitment obligations, the definition of force majeure events and the consequences of declaring force majeure, and certain issues arising with respect to dispute resolution. This article was originally developed as part of a project undertaken by a committee of the Association of International Petroleum Negotiators ("AIPN"). Parts of the article were presented at an AIPN International Petroleum Agreements seminar in London in March 1998 and was revised and presented to a similar conference in Vail, Colorado which took place from 30 June to 2 July 1998.

\section{APPRAISAL AND COMMERCIALITY}

\section{A. INTRODUCTION}

When petroleum is discovered in a well, it may not be of the quality and a quantity sufficient to justify its exploitation. Put another way, a discovery may not prove to be a "commercial discovery." Usually, additional drilling is required to verify the size, shape and nature of the petroleum reserves; in addition, an economic analysis may be carried out. Many international petroleum agreements ("IPAs") do not provide for an appraisal phase and move directly from the exploration to development phases, without addressing the critical step of appraising commerciality. IPAs should include a provision to deal with the appraisal of the discovery, which allocates enough time to analyze the discovery.

Both the host country (the "HC") and the international oil company (the "IOC" or the "Contractor") have a great deal at stake in the exploration, exploitation and production sharing of the HC's oil reserves and, therefore, careful drafting of appraisal and commerciality provisions in IPAs is necessary for both parties to protect their respective interests.

\section{B. Overview of Appraisal Provisions}

Appraisal provisions present interesting issues for those drafting IPAs. The appraisal clause has increasingly become the focus of HCs as a result of the recession in the 1980 s and the belief that marginal prospects and gas discoveries would be ignored by 
the IOCs even though they were appropriate for domestic market use because of the economic value to the $\mathrm{HC}$. $^{\prime}$

Whereas the government's interest is to evaluate its own petroleum potential thoroughly, IOCs are concerned with spending capital and coordinating operations in order to maximize project and shareholder value.

Many contracts now provide for a due diligence requirement which obliges IOCs to appraise their discoveries. The contractual terms have become specific, requiring the contractor to submit to the $\mathrm{HC}$ all relevant information concerning the discovery, including an assessment of its possible commercial interest and an appraisal plan.

Clauses with detailed appraisal terms can be difficult to negotiate. Because of the conflicting interests, what constitutes an appropriate appraisal area or appraisal program may be difficult to define. For example, working in parts of the contract area outside of the area where the discovery was made can provide a valuable part of an appraisal plan to evaluate a discovery. Such evaluation may provide useful information about the original area or it may result in new discoveries which if developed or considered in addition to the original discovery would demonstrate commerciality.

\section{Rationale}

The IOC would prefer to develop discoveries which are large enough to support significant exports. The HC is often concerned with supplying domestic demand and in those circumstances would prefer to develop more marginal fields as well. This has led to HC concerns that IOCs would not reveal discoveries of these marginal fields. To alleviate these concerns, HCs require IOCs to submit detailed appraisals within fixed time periods and then assist in the determination of whether a discovery is commercially exploitable. Disputes between HCs and IOCs can arise during the transition from the exploration phase to the development phase if procedures for dealing with these issues are not in place.

As well, the Contractor must establish a commercial accumulation within the exploration period or risk losing its rights. Under many contracts the critical issue is being able to forecast the time period and requirements for establishing a commercial accumulation. This highlights the need for an appraisal phase to come between exploration and drilling to extend the time period to allow for proper appraisal.

\section{A Peruvian IPA provides an example:}

["Commercial Find" means] an Oil find within the period stipulated in Article 3.2 which in the opinion of the Contractor, justifies termination of the Exploration phase and implementation of the Development programmes in accordance with the provisions of Article $5.1 \mathrm{~A}$.

C.P. McPherson, "Recent Developments in Petroleum Laws and Contracts" (Proceedings of the IBA Seminar on International Energy Law) International Energy Law, Houston (New York: Matthew Bender, 1984) at 42-43. 
5.1 The Exploitation phase shall commence on the day following the declaration of a Commercial Find. The Exploitation starts with Development. At the time the Contractor declares a Commercial Find, he undertakes to:

a) Submit to PETROPERU and the General Directorate of Hydrocarbons, within one hundred and twenty (120) days of said declaration, an initial Development Plan;

b) Initiate the Development of the Contract Area within one hundred and eighty (180) Days following said declaration of a Commercial Find; and

c) Initiate, within twenty-four (24) Months of the Day on which he declares a Commercial Find, construction of the Pipeline system, as hereinafter provided. ${ }^{2}$

At the expiry of the exploration period, many IPAs provide that IOCs retain exclusive rights of exploitation to the commercial discovery areas but must surrender the other parts of the contract area not deemed commercial in the absence of a commitment to development. An appraisal period allows for better delineation of a discovery prior to commitment to a development plan or relinquishment.

\section{ISSUES}

\section{DEFINITION OF A DISCOVERY}

The definition of a discovery in many IPAs is phrased in general terms. For example:

Commercial discovery means a discovery of petroleum which has been duly evaluated ... and which can be produced commercially according to good oilfield practice, after the consideration of all pertinent technical and economic data. ${ }^{3}$

This is, however, a vague definition which could create uncertainty and promote subjectivity.

In Qatar, a "Commercial Discovery" is defined to be an occurrence where a well or wells within the contract area, completed and tested in accordance with good petroleum industry practices, have been found capable of producing petroleum commercially with a reasonable rate of return on the project, taking into account recoverable reserves, production rates, reservoir performance, facilities required, available technology, estimated prices, and generally all relevant technical, financial and economic factors.

"Commercial Discovery" in Oman has been defined as:

In the case of crude oil, the initial discovery of crude oil in a well or wells within the contract area which has or have been completed and tested in accordance with good oilfield practice and found

2 K.W. Blinn, et al, International Petroleum Exploration and Exploitation Agreements: Legal, Economic and Policy Aspects (London: Euromoney Publications, 1986) at 141-42.

$3 \quad$ Ibid. at 138. 
capable of producing between them twenty-five thousand $(25,000)$ Barrels per day for a period of thirty (30) consecutive days. The date of discovery of crude oil in commercial quantities (hereinafter called the "Discovery Date") shall be the date of testing on which a well within the Contract Area is found capable of producing by itself or together with other wells within the contract area already drilled and tested the aforesaid twenty five thousand $(25,000)$ barrels of crude oil per day for a period of thirty (30) consecutive days.

These two definitions show contrasting approaches. The Qatari definition is more general but is a description of the many technical and economic factors that would be considered in making an exploitation decision, whereas the Omani definition is specific and objective in terms of productive capacity without regard to other significant factors.

Under the Brazilian IPA, a field is considered to be commercial only if its expected oil production indicates net incomes at least equal to the financial liabilities that the discovery generates with respect to exploration, development and remuneration reimbursements. The net income of the field under evaluation is based on gross income corresponding to its anticipated oil production, after the deduction of all direct costs of production, collection, storage and transportation of oil to the delivery terminal, the applicable overhead and Brazilian severance taxes, but without apparent regard to the time value of money. Where a discovery meets the commerciality test, the IOC is not required to proceed with the project, but Petrobras may proceed with development at its sole risk.

\section{REPORTING A DISCOVERY}

Once a discovery of petroleum is made, the IPA will stipulate reporting of the find. Some IPAs require the immediate reporting of the discovery to the appropriate authorities of the HC. For example, in Bangladesh, if petroleum is encountered in an exploratory well, the $I O C$ is required to notify PetroBangla of such a discovery immediately. The IOC then has thirty days to notify PetroBangla whether or not it proposes to undertake an appraisal.

China is another example of a country which imposes an immediate notification requirement. All discoveries must be reported promptly and, if considered worthy of appraisal by either the HC or the Contractor, the IOC must submit an appraisal work program within ninety days of the decision to proceed. The worthiness of the appraisal can be approved by the Contractor alone, but the appraisal work program itself must be approved by China.

The reporting of a discovery should not be a contentious issue among the parties provided that the IOC is given a reasonable amount of time to appraise the discovery before development and production must commence. An immediate reporting requirement, coupled with little or no opportunity for appraisal, provides a disincentive for IOCs to report a discovery. The IOC may delay reporting of the find until it has had an opportunity to assess the discovery and determine its commerciality. 


\section{TIME PERIOD FOR APPRAISAL}

Recently, HCs have shortened appraisal times to accelerate relinquishment of the contract area, allowing the HC to contract with other investors. This is a disincentive to IOCs. Larger appraisal areas and longer appraisal times are obviously advantageous to IOCs because discovery often takes place on land outside the prospective area. Secondly, "commerciality" often depends upon economies of scale; often several contiguous areas must be explored and found productive before any single area can be commercially produced. Granting sufficient time and area in the IPA allows effective exploration and development.

Australia provides an example. Discoveries formerly reverted to the Crown when the exploration permit expired, unless the permit had been converted into a production licence. Obtaining a production licence involved heavy minimum annual expenditure conditions. On default, the production licence was cancelled. Because of the frequency of default, Australia developed a new policy. Australia now grants an explorer a retention lease upon making a discovery which provides an incentive for exploration. This lease grants the explorer exclusive tenure over the discovery for five years. It is renewable if it can be shown that the discovery is still not commercially viable under prevailing conditions.

\section{COST OF APPRAISAL}

Exploration and appraisal activities undertaken by IOCs are normally done at their sole expense. An IOC may be more reluctant to carry out an appraisal of a field it considers marginal if it bears the sole cost of appraisal. An HC obviously would prefer that the IOC bear the cost as it has the incentive to produce these marginal fields for domestic supply. Provided that appropriate cost recovery conditions are in place, IOCs will generally be willing to bear the financial burden of appraisal; otherwise, some form of mutual cost-sharing may be required.

\section{APPRAisal Plan AND REPORT}

In most countries, the appraisal plan or report is submitted by the IOC for advance approval by the HC. The IOC must justify its declaration of commerciality by submitting a development plan containing, at a minimum, an economic assessment of the discovery. There are varying levels to which the parties participate in developing the plan, but final approval usually rests with the $\mathrm{HC}$.

\section{a. Appraisal Plan}

In Vietnam, for example, upon a discovery in the contract area, the IOC must notify PetroVietnam in writing, then establish an evaluation work program, and carry out appraisal work for up to eighteen months. Upon completion of the appraisal work, if the IOC deems the oil discovery to be commercially exploitable, the IOC shall notify PetroVietnam that it is a commercial discovery. Within ninety days, the IOC must then establish a development plan. 
In the Ivory Coast, a permit is issued to the IOC upon discovery to allow for appraisal to take place, upon request within six months after the date of the notification of the discovery. The government may not reject or modify the IOC's proposed program if it complies with good international petroleum industry practices. The Contractor is then granted a two-year exclusive appraisal authorization from the date of approval of the work program and budget.

\section{b. Appraisal Report}

The results of the appraisal are generally required to be included in an appraisal report. For example, in Brazil, upon completion of commercial evaluation, the IOC must submit a report which includes reservoir engineering studies and an economic evaluation demonstrating whether the discovery is commercial or not, together with preliminary development programs and budgets.

A recent Norwegian form of IPA contains the most detailed statement of the elements for determining the commerciality of a discovery. The IOC is required to submit to the management committee of the venture and the Norwegian ministry concerned, a statement on whether the discovery is commercial, as well as a report which includes the following:

(a) proposed program, including alternatives, for exploitation of the discovery if it is regarded as commercial, stating:

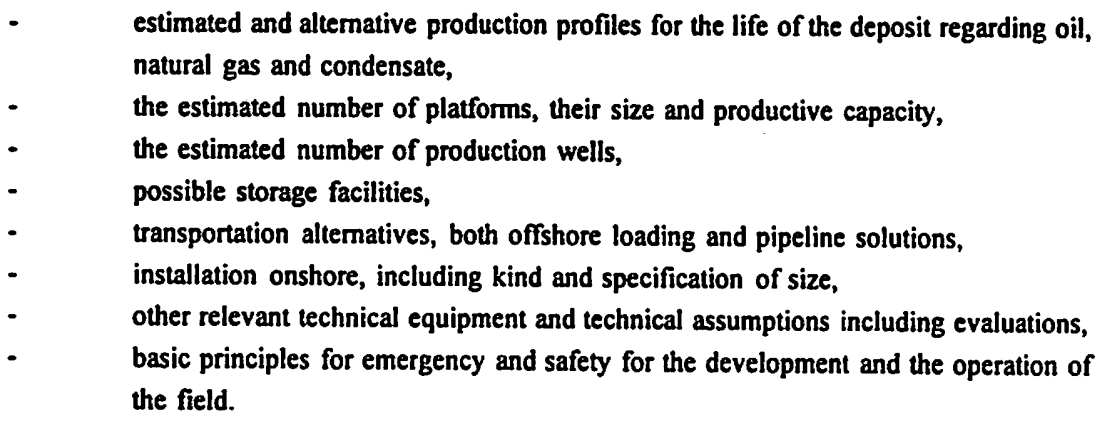

(b) the proposed program shall include specified cost estimates with calculations of the profitability of development and exploitation of the discovery, taking into consideration its location, the water depth, meteorological conditions, cost estimates as given in letter (a), the price of petroleum and other relevant economic data.

\section{Fallure to Establish an Appraisal Program}

The failure to establish an appraisal program will generally result in the $10 \mathrm{C}$ relinquishing its rights to the discovery area. 


\section{SOLE RISK}

The Mozambican appraisal clause, shown below, gives an example of provisions dealing with the situation where the IOC has prepared the proposed appraisal program and budget, but has made its own initial determination that the "discovery" does not merit further expenditure or work. The clause allows the HC to develop the field at its sole risk and expense if it so desires.

\footnotetext{
Contractor shall advise HC immediately when petroleum is discovered in any well. Within 90 days from the date of such notice, Contractor shall submit to $\mathrm{HC}$ a written report setting forth all pertinent information in respect of the drilling of such well together with Contractor's recommendation as to whether or not appraisal ought to be carried out. If Contractor considers that further drilling is required or that such well ought to be completed for the production of petroleum, then such report shall include an Appraisal program of such discovery and the budget.
}

Not later than $\mathbf{3 0}$ days from the date of submission of the report, the parties shall meet to discuss the Contractor's recommendations with a view to approving them or mutually agreeing on amendments.

If the Contractor fails to proceed with the approved Appraisal program and budget within 6 months from the date of approval, the portion of the Contract Area covered by such Appraisal program shall, at the end of the exploration period be excluded from the Contract Area; provided that the Contractor may sooner elect to exclude that area from the Contract Area. Contractors shall not be entitled to any remuneration, reimbursement or any right whatsoever, in or to any petroleum obtained from that part of the Contract Area.s

In China, the IPA provides for the reverse. If the HC decides the field is not commercial, the Contractor may proceed at its sole risk and cost to develop it, and it is deemed to be a field in which the HC oil company has no participating interest. If the IOC does not consider the discovery commercial and the HC oil company decides to develop the field, during the development period the IOC may decide to participate by paying 49 percent plus deemed interest on all development costs incurred and an additional unrecoverable penalty of 300 percent of that amount. The HC oil company does not have a reciprocal right to back into a field once it decides the field is not commercial.

\section{E. Overview of Commerciality}

Once appraisal is completed, commerciality must be determined. Some IPAs allow the Contractor to decide whether or not to commence development operations, while others leave the decision to the HC. Most IPAs have a general commerciality requirement which places the burden of proof on the Contractor to determine whether the development of a discovery is economically beneficial for both parties. The benchmark for obtaining commercial status for a discovery is usually a predetermined percentage of gross take for the government. Under many commerciality clauses, a discovery cannot be developed unless it is granted commercial status by the host 
government. The grant of commercial status marks the end of the exploration or appraisal phase and the beginning of the development phase.

\section{F. Rationale of Commerciality Clauses}

Who determines whether or not a discovery is economically feasible and should be developed is often a contentious issue because many situations arise where accumulated exploration expenditures are so substantial that by the time a discovery is made, these sunk costs have a huge economic impact on whether to proceed with the exploitation of the discovery. From the perspective of the IOC, sunk costs upon development will flow through cost recovery (or will be used as deductions), and they can represent considerable value. But they represent a liability, or a cost, as far as the HC government is concerned. If cost recovery is too great, then the government may end up with only a small percentage of the gross production, depending upon the contractual and fiscal structure.

\section{G. COMmerciality IsSUeS}

\section{WHO DETERMINES COMMERCIALITY}

\section{a. The International Oil Company}

In most IPAs, the determination of the commerciality of a discovery is practically left to the IOC, which is responsible for the subsequent development and production investments.

Some Egyptian IPAs grant the IOC the right to declare commercial a well with a lower daily production than the minimum rate indicated in the contractual definition of a commercial well:

...except that contractor shall also have the right to give such notice of commercial discovery... even if the well or wells are not 'commercial' within the definition of 'commercial well', if, in its opinion, a reservoir or a group of reservoirs considered collectively, could be worthy of development.

In Oman, the IOC has the right to determine, on the basis of technical and economic data contained in the appraisal report, that a discovery of crude oil in the contract area which has been tested in accordance with good oilfield practices is a commercial discovery.

Leaving the declaration of commerciality to the IOC obviously carries risk for the HC. It leaves open the possibility that a discovery may not be developed because the IOC has better investment opportunities elsewhere, even though the discovery in question could itself be profitably developed to provide domestic supply. Because of the differing views of what constitutes a commercial discovery, some recent IPAs have attempted to specify relatively objective standards for determining whether a discovery is commercial and should be developed. 


\section{b. Mutual Declaration of Commerciality}

Increasingly, HCs have imposed provisions which provide for their participation in the determination of commerciality. Thus, the declaration of commerciality would be made by mutual agreement as set out in the IPA such that the government cannot require the Contractor to exploit the deposit if the IOC does not deem it to be economically feasible. This would place an unfair burden on any $I O C$ and provide strong disincentive to exploration in the HC.

If the parties under one form of Brazilian IPA fail to agree on commerciality, the issue will be determined by arbitration and if, in the IOC's opinion, the field cannot be satisfactorily developed in accordance with the plan specified in the arbitration award, the IOC may relinquish its interest in the development area. The IOC will then not be entitled to any reimbursement or remuneration with respect to the production derived from that field.

In Bangladesh, with the evaluation report the Contractor must submit a declaration in writing to PetroBangla either:

a) that it has determined the discovery is a commercial discovery and upon such Declaration of Commercial Discovery, Contractor shall be obliged to develop the Discovery and commence Commercial Production; or

b) that it has determined that the Discovery is not a Commercial Discovery, in which event the respective Appraisal Area shall be relinquished, with such relinquishment being credited against the obligations under Article; or

c) that it has determined that the Discovery is a Significant Discovery of Oil, which may become a Commercial Discovery conditional upon the outcome of further work under an Exploration or Appraisal Program in areas outside the Appraisal Area, for which further work Contractors committed itself; or

d) that it has determined that the Discovery is a Significant Discovery of Natural Gas."

This notice leads to mutual discussion for agreement that a commercial discovery exists.

China takes a somewhat different approach. When the Chinese government reviews the appraisal report of an IOC, the parties must unanimously agree that the field has commercial value, at which point the appraisal report is submitted to both the state oil corporation and the government authorities for review and approval. Once approved, development operations must proceed quickly and continuously, as on default the state oil corporation reserves the right unilaterally to expropriate the Contractor's interest in the field. 


\section{c. Host Country}

There are situations where the HC is the sole determinant of commerciality. In Qatar, the $10 \mathrm{C}$ has the opportunity to make a declaration of commerciality, but the government also has that ability, on default by the IOC. Once a discovery has been made, if the Contractor has not presented a development plan within the stipulated time period, the government may declare the discovery to be a commercial discovery and instruct the Contractor to develop the discovery according to a development plan proposed by the government. The Contractor then has six months to elect by written notice to the government to develop such discovery. If the Contractor fails to respond within the period, elects not to develop the discovery, or fails to propose a development plan for such discovery in the manner and at the times specified, then the discovery becomes fully owned by the Government without any consideration, compensation or payment to the Contractor.

\section{The Special Case of Indonesia: first tranche Petroleum}

The second generation IPA in Indonesia required a declaration of commerciality. Cost recovery was applied based on accepted accounting principles without a ceiling. But when oil prices fell in the early 1980s, problems were created. A new field, with high costs and a small reserve, might not provide income to the $\mathrm{HC}$ during its entire lifetime. To protect the HC's income, Pertamina created a new rule, namely, that a new field could only be declared "commercial" if there was a positive cash flow for the government. This created problems.'

The third generation IPA eliminated commerciality problems. First tranche petroleum ("FTP") was introduced in 1988. The FTP sets aside, prior to cost recovery, 20 percent of total oil produced. This 20 percent FTP is split between the government and the Contractor, based on the prevailing PSC arrangement. Based on the 1984 tax law, the Government received 71.1538 percent, while the contractor received 28.8462 percent of FTP, which then was added to the Contractor's other income and taxed accordingly. The government, through this mechanism, is guaranteed a minimum income of 14.23 percent from any operation. This FTP requirement has no effect on companies already producing, and is primarily designed to solve the commerciality issue of small fields in the early stages of production.

\section{GOVERNMENT PARTICIPATION}

In Colombia, the commerciality issue is complicated by Ecopetrol's 50 percent carry through the exploration and delineation phases. Government participation effectively begins at the point that commercial status is granted. If the government does not agree that the discovery can justify development, the Contractor may still go forward. In that case, the government back-in does not take effect until the Contractor recoups 200 
percent of its investment. Up to that point, the government receives a 20 percent royalty.

If Ecopetrol agrees that a commercial field exists, it notifies the IOC within ninety days and must reimburse the IOC 50 percent of costs of drilling and completion of the first two years of exploration and 20 percent of costs of wells drilled in later years.

This issue is of particular importance with progressive regimes where government take is based more on profitability than gross revenues. If a marginal field is developed under a progressive regime then the government's share of revenues could be both small and substantially delayed. This is an important consideration that is critical in fiscal design. Systems with significant limits on the Contractor's access to gross revenues have little need for a commerciality requirement. HCs that have no cost recovery limits and low royalties often protect themselves with a commerciality clause. ${ }^{8}$

\section{H. COMMERCIALIZATION fOR NATURAL GAS}

The commercialization process for natural gas is complicated by additional parameters largely related to whether there exists a gas market connected by pipeline. While one can declare an oil field to be commercial on the basis of a general expectation as to future oil prices, one cannot determine the commerciality of a particular gas field without first identifying the specific market for that field's production. 9 The process for commercialization of gas discoveries must therefore include studies to identify a feasible market and the feasibility of constructing downstream facilities, coordination of upstream and downstream activities and negotiation of gas sales to major consumers. This may result in the IOC "creating" a market for the gas, by developing or arranging for the development of an electrical power or liquified natural gas project.

\section{MINIMUM WORK COMMITMENTS}

\section{A. INTRODUCTION}

The principal risk involved with oil and gas production relates to the recovery of the capital outlay for exploration activities. ${ }^{10}$ As a result, the section within a typical IPA where the capital outlay is established, often called the "minimum work commitments" section, is crucial. Negotiators for both IOCs and HCs must take care that this particular

ง Joumal 114 at 115 .

9 G.B. Greenwald, "Exploration and Production Agreements for Natural Gas" (Proceedings of the advanced seminar on petroleum and energy resource law organized by the IBA's Section in Energy and Natural Resources Law in Sydney, Australia, March 1988) and Energy Law '88 (London: Graham \& Trotman) 776 at 782.

so See D. Johnston, International Petroleum Fiscal Systems and Production Sharing Contracts (Oklahoma: PennWell Publishing Company, 1994) at 52. 
section of the IPA will include mechanisms that not only address their respective interests, but that create the greatest chance for a commercial discovery to be made.

The interests of IOCs and HCs coincide in some important aspects and conflict in others. Generally, both the IOC and the HC desire that commercial amounts of hydrocarbons be discovered and produced expeditiously, for the benefits of production fall to both parties. In principle, most IPAs are structured to allow the IOC sufficient maneuverability to achieve this mutual goal. However, in pursuance of this goal, an IOC will undoubtedly favour flexibility; specifically, an IOC may seek to delay work commitments to await higher oil prices, to hold acreage for future needs, or to tie up land to foil competitors - all to increase long-term profits. In contrast, the HC will often seek to maximize its control over exploration and production to ensure quick and thorough results. A well-crafted minimum work commitments section will obviously balance the interests of both sides, and focus them toward a commercial discovery.

\section{B. Components of Typical Minimum Work Commitment Clauses}

\section{StRucture of THE EXPLORATION PERIOD}

Most minimum work commitments sections are structured to provide IOCs the maximum flexibility to withdraw from nonproductive exploration programs while allowing the $\mathrm{HC}$ to take back lands that will not be used in a production program. The exploration period will typically be subdivided into discrete work commitment periods to allow the $\mathrm{HC}$ to verify that the IOC is adequately advancing its work commitments. A typical IPA will contain an exploration period of up to six or seven years that is itself divided into two to three subperiods. Within each subperiod of the exploration period, the agreement will provide for some minimum level of exploration activity, be it the acquisition of seismic data, the drilling of exploratory wells or minimum capital expenditures. Generally, the IOC's right to continue exploration and drilling in the next subperiod will be made contingent upon the fulfillment of the work commitments that correspond to the current period. One such agreement is an EPSA in Qatar, which provides the following:

\section{ARTICLE 5 - EXPLORATION PHASE}

The exploration phase shall be for a maximum period of seven (7) years divided into two (2) successive Exploration Periods.

\subsection{First Exploration Period}

The first Exploration Period shall commence on the Effective Date and shall be for a duration of four (4) years. 
5.2.1 On or before the date of expiry of the first Exploration Period, CONTRACTOR shall give a written notice to the GOVERNMENT whereby CONTRACTOR shall either;

(i) subject to Article 11, enter the second Exploration Period;

(ii) subject to Article 10, retain area(s) of Commercial Discovery, if any, and relinquish all other portions of the Contract Area; or

(iii) terminate this Agreement effective on the date of expiry of the first Exploration Period.

5.2.2 If, on or before the date of expiry of the first Exploration Period, CONTRACTOR fails to give the written notice referred to in article 5.2.1, then this agreement shall be deemed terminated effective on the date of expiry of the first Exploration Period.

5.2.3 Subject to CONTRACTOR's fulfillment of the minimum work commitments, in the event of the termination of this Agreement pursuant to Article 5.2.1 (iii) or 5.2.2, neither Party shall have any further claims against the other Party in respect of such termination, except as provided in Article 28.6.

5.3 Second Exploration Period

Provided CONTRACTOR satisfies the requirements of Article 5, the second Exploration Period shall commence on the first day following the date of expiry of the first Exploration Period and shall be for a duration of three (3) years.

- The preceding clause is a good example of a provision that provides flexibility for the IOC. The exploration period is divided into only two subperiods, each fairly lengthy. This structure will allow the IOC to perform its obligations at its own pace. The $\mathrm{HC}$, by contrast, has a diminished ability to verify that the $\mathrm{IOC}$ is advancing its obligations in a timely fashion. Some IPAs have exploration periods of about three years divided into three one-year subperiods.

Depending on the level of control that the HC wants to exercise over the advancement of the work commitment obligations, the number and duration of the successive exploration periods can be altered. In a 1992 Colombian Association contract, the exploration terms and conditions included six successive periods of one year with very specific and detailed work commitments corresponding to each year:

5.1.1 During the first year counted from the Effective Date of this contract, the ASSOCIATION is obligated to execute the reprocessing of one hundred eighty (180) kilometres of available seismic and to acquire a program of at least 80 kilometres of new seismic information. During the second year, the ASSOCIATION will bring about the drilling of two exploratory wells until it penetrates the formations that may produce Petroleum in the area with the option of running only 70 kilometres of seismic testing and drilling one exploratory hole until reaching 
penetration of the formations that may produce Petroleum in the area. At the end of each year, the ASSOCIATION will have the option of terminating the Contract, but only after having fulfilled the previous mentioned obligations.

5.1.2 During the third year, the ASSOCIATION will drill two exploratory wells until reaching penetration of the formations that may produce Petroleum in the area. At the expiration of this year the contract will terminate, if the extension pursuant to 5.2 of this clause has not been solicited and authorized or if a Commercial Field has not been discovered.

5.2 If the ASSOCIATION has satisfactorily fulfilled the obligations stated under Clause 5, ECOPETROL at the request of the ASSOCIATION will extend annually, up to three additional years, the Exploration Period and during each extension the ASSOCIATION will be obligated to carry out exploration projects in the area, consisting of the drilling of two exploratory wells until penetrating the formations that may produce Petroleum in the area.

While such an arrangement tightens the reins on the pace at which the $1 O C$ must perform its obligations, it also provides a quick exit in the event that exploration efforts are fruitless. The disadvantage of this approach is that one-year time periods may not provide the IOC with the needed flexibility to complete the work corresponding in that period, necessitating frequent and time-consuming negotiations with the $\mathrm{HC}$ for extensions or carryovers.

Another common mechanism to ensure that the IOC quickly resumes its obligations involves specifying a date by which exploration operations must begin, or even describing what particular operation must be commenced. An example is found in an Egyptian IPA which requires its contractor to "commence Exploration operations not later than six (6) months after the Effective Date." A Bolivian IPA went a step further and required that the first well be commenced before a specified date and defined commencement as "the day the drilling rig is in place, rigged up, actual drilling has started and drilling rates are in force."

The ultimate structure of the exploration period will obviously depend on the bargaining positions of the parties, the knowledge of the parties about the potential reserves in the contracted area, and a myriad of other factors. However, the parties' mutual interest to determine the extent of hydrocarbon reserves is generally better advanced with a mechanism that spreads the work commitments over several subperiods, thus linking work commitments and exploration results. The IOC, in this way, reduces its exposure to being committed to massive expenditures in a nonproductive field; at the same time, the $\mathrm{HC}$ is able to obtain greater overall work commitments where the possibility of commercial production exists.

\section{SEISMIC AND OTHER DATA}

Almost without fail, the reprocessing or acquisition of new seismic or other data will be included as a minimum work commitment. HCs require this information for various 
purposes. The first is a policing function; by specifying the type and quantity of geological data, the HC can ensure that the IOC is performing its job effectively. Secondly, the HC can take the data obtained by an IOC and correlate it with data from other sectors to assess the likelihood of the existence of other prospective fields within its borders. Thirdly, the HC can use the data to attract more investment.

IPAs vary with respect to the level of detail with which they specify data acquisition obligations. Thus in an Omani EPSA, the HC required only the following:

Within the initial term the company shall:

(a) Complete approximately km of seismic shooting;

(b) Reprocess and reinterpret approximately km of seismic data:

A recent Qatari IPA provided a more flexible phrase:

[The IOC shall] carry out an integrated multidisciplinary study, based upon existing information as well as data obtained from activities under the above items to assess the hydrocarbon prospectivity and potentiality of the Contract Area.

On the other extreme, a recent Nigerian IPA required that:

[D]uring the First Phase of the First Exploration Period, the Company undertakes to carry out the following work program:

(i) Geological and surface studies;

(ii) Geochemical analyses:

(iii) Petrographic analyses;

(iv) Interpretation of satellite images;

(v) Interpretation of aerial photographs;

(vi) Reinterpretation of gravimetric data;

(vii) Acquisition of new gravimetric data;

(viii) Petrophysical analysis;

(ix) Fluid test anajyses; and

(x) Reinterpretation of seismic data.

The level of specificity with respect to seismic and other data requirements will, again, vary with the amount of control that a HC desires to exercise over the IOC. Where the data acquisition requirements are too stringent or specific, it restricts the IOC from making case-by-case decisions about the optimal exploration techniques. Where they are vague, the HC loses the capacity to enforce the minimum levels of data acquisition necessary for correlating with other information it may possess. 


\section{MINIMUM WELL-DRILLING REQUIREMENTS}

Another pervasive component of minimum work commitment clauses is the requirement for a minimum number of wells to be drilled. Such requirements are generally written to specify the depth that a well must reach. Hence, in Gabon, a 1991 IPA stated that:

The well specified in the exploration period defined in Article 3.1 (3 year period) will be drilled to a minimum depth of fifteen hundred meters $(1,500 \mathrm{~m})$ True Vertical Depth, or until the Kango geological formation is penetrated for at least fifty meters, if it is encountered above the contractual depth. If, at fifteen hundred meters $(1,500 \mathrm{~m})$ True Vertical Depth, said formation has not been encountered, the Parties will meet in order to examine the desirability of continuing the well in the interest of each.

While provisions with this level of specificity may be written where the parties already possess significant information about the prospect, provisions that do not allow for some flexibility impose artificial restraints on the IOC, which may shift focus away from the ultimate goal - a commercial discovery - toward a rote fulfiliment of work obligations. Since this would be mutually self-defeating, numerous IPAs allow escape mechanisms for drilling depths, in order to achieve the maximum benefit. Witness a Nigerian clause:

Any drilling of an exploration well that the Company shall carry out under Article 25.2 shall be performed according to the standards of the international petroleum industry and shall be considered as having been achieved when the first of the following conditions has been complied with: (i) the well has reached its depth or stratigraphic objective, (ii) it consists of a discovery well, (iii) it has reached the basement, (iv) it meets impenetrable substances, excessive geothermal gradients or another condition of unfavourable drilling which, in accordance with the standard used in the international petroleum industry, show that drilling must be stopped.

Similarly, in the event that a prospect is non-drillable, the parties should provide for substitute performance, perhaps by allowing the Contractor to gather seismic data instead.

With respect to requirements specifying a minimum number of wells to be drilled, the parties should be aware of other issues related to the classification of exploratory wells. This can arise in various scenarios. For example, an operator may discover hydrocarbon reserves on the first of a two-well commitment, drill a second three miles away and find that the accumulation spans to the location of the second well. This creates room for the $\mathrm{HC}$ to argue that the second well was merely a delineation well, and that another exploratory well will be required to comply with the IPA. A second example is where two wells were planned for separate fault blocks. The first well is dry, so the operator decides to sidetrack the first well to drill directionally into the second fault block. While this process tests both blocks, the government may argue that a second exploratory well is still required." To avoid such misunderstandings, parties should carefully define the required "exploratory wells." 


\section{MINIMUM SPENDNG COMMTMENTS}

Flexibility is, once again, the bargaining focus in fixing minimum spending commitments. The type of contractual arrangement that will be of the greatest benefit of the IOC is one where there is no specific minimum expenditure obligation. This may be true as well for HCs, since for them it is important that the appropriate amounts of work be performed. The reality is, however, that many IPAs require minimum expenditures, fixed at a specific capital amount. A recent Egyptian IPA provides a fairly basic example in its requirement that "Contractor shall spend a minimum of six million $(6,000,000)$ US Dollars on Exploration operations and activities related thereto during the initial three (3) year Exploration period." While such an approach is common, it can lead to a non-results focus. Thus, in a recent Nigerian IPA, it was provided that:

The minimum amount to be spent by the Company to fulfil its work commitments during the First Phase of the First Exploration Period shall be two hundred (200) million C.F.A. It is understood, however, that the Company's primary commitment is the completion of the work program. Fulfillment by the Company of its work commitments shall release the latter from any obligation to invest a minimum amount of expenses.

This results-oriented approach encourages efficiency. The IOC will not simply be spending money for spending money's sake. A similar approach, taken in a Gabon IPA, adds yet another dimension. It requires that a specific amount be spent on exploration, but later states that:

The Contractor is required to meet its work commitments for an exploration period even if this entails the Contractor exceeding the dollar amount estimated for that period. On the other hand, if Contractor has met the work commitments for a given exploration period for an amount less than the amount estimated for that period, it is considered to have met those commitments.

Because such a clause has the effect of reducing the minimum expenditure "requirement" to a mere "estimate," it untethers the IOC from any artificial tie to a specific sum.

It is not uncommon with respect to minimum capital expenditure requirements for the $\mathrm{HC}$ to seek the amount of any underexpenditure within a period or subperiod. To that end, an Omani IPA established that:

In the event that the Company upon conclusion of the initial year term hereof has not fulfilled its minimum work and financial obligations as set forth in Article 3.1 above, the Company shall pay to the Government the difference between (the minimum contracted amount) U.S. dollars and the amount actually spent by the Company on Petroleum Operations hereunder to the extent that the Company's said expenditures are less than (the minimum contracted amount) U.S. dollars.

This type of provision ensures the HC that it will get the full benefit of the contracted minimum expenditure. 
Finally, with respect to minimum expenditure requirements, to reduce exposure to currency risks any monetary commitments stated as specified sums can be indexed to account for exchange-rate fluctuation.

\title{
5. CARRYOVER OF WORK OR EXPENDITURES REQUIREMENTS
}

Recognizing that rigidity in forcing exploratory well, data acquisition, or expenditure requirements into ironclad time-frames frustrate results, a typical minimum work commitment section will allow for the carryover of obligations. The Egyptian IPA provides that:

\begin{abstract}
Should CONTRACTOR spend more than the minimum amount required to be expended or drill more wells than the minimum required to be drilled or acquire more seismic than the minimum required during the initial three (3) year Exploration period, or during any period thereafter, the excess may be subtracted from the minimum amount of money required to be expended by CONTRACTOR or minimum number of wells required to be drilled or minimum kilometres of seismic to be acquired during any succeeding Exploration Period or Periods, as the case may be.
\end{abstract}

A Gabonese provision, stated with more economy, provides:

Any work carried out, or investment expended, in excess of what is above specified, in an exploration period, may be credited to a subsequent period.

The benefits of carryforward are clear; they allow the IOC to progress through its exploratory program faster than it would be able to otherwise, in that it may perform its obligations faster than outlined in the IPA. On the other hand, a Contractor who is duly performing contract obligations may be slowed for a legitimate reason, and will benefit from a mechanism that will smooth out the cycles inherent in performing exploration activities. Some contracts provide for the carryover of expenditure obligations that were not fulfilled, e.g.:

If during any Contract Year Contractor should spend less than the amount of money required to be so expended, an amount equal to such under-expenditure may, with Pertamina consent, be carried forward and added to the following year.

\section{Performance Guarantees}

Performance guarantees, with their various faces, are a common means of providing HCs with additional assurances that the minimum work commitments will be performed. Thus, the HC may require an unconditional corporate guarantee from the parent company of the subsidiary operator. The IOC will prefer this approach because it is granted with no payment of a commission to a third party guarantor. The HC, however, will probably prefer another method given that to enforce a corporate guarantee will require recourse to a court or arbitrator.

Alternatively or in addition to the parent company guarantee, the $\mathrm{HC}$ will negotiate for a letter of credit issued by an international bank. While there will be a cost, the IOC 
may be able to obtain the best rate from a bank that is courting the IOC for its business should a discovery be made. In the further alternative, an HC state-owned bank may issue a guarantee. The fee paid by the IOC for such a guarantee instrument will be higher than a letter of credit, but will provide the maximum security for the HC. Bank guarantees should reduce as the IOC meets its commitments.

Guarantee clauses will evince various repayment structures, a common one being as follows:

As a condition precedent to the effectiveness of this Contract, Contractor shall provide a security by means of a bank guarantee acceptable to the Ministry corresponding to the total minimum Exploratory Expenditures for the first three (3) contract years. Upon prior confirmation by the outside independent auditors of the expenses incurred, the security shall be reduced annually to the extent that the Contractor has spent the corresponding minimum amounts fixed. Upon termination of this Contract, if Contractor has not expended sums at least equal to the respective total minimum Exploratory Expenditures, the balance of the security corresponding to the unexpended minimum Exploration Expenditures automatically shall be paid to the Ministry.

\section{WORK PROGRAM AND INFORMATION REQUIREMENTS}

Almost all HCs desire to exercise some supervisory authority over the quality of the exploration being performed by the IOC. Because the required capital outlays not only provide information about the specific contract area set aside for the IOC, but allow the $\mathrm{HC}$ to correlate data with that from other contract areas, it is imperative that the information be accurate. To this end, many IPAs will attempt to lay out the specifics of work programs, while providing correction mechanisms for data that may be errant.

An Ivory Coast IPA provides a standard "Approval of Annual Work Programs and Budgets Clause":

5.1 At least three (3) months before the beginning of each Calendar Year, or for the first Year, within one (1) month from the Effective Date, the Contractor shall prepare and submit for approval to the Government an Annual Work Program together with the related Budget for the entire Delimited Area, specifying the Petroleum Operations and the costs thereof that the Contractor proposes to perform during that Calendar Year or portion of a Calendar Year in the event an exploration period will terminate prior to the end of such Calendar Year. In the event of renewal of the exclusive exploration authorization, the Contractor shall, within thirty (30) days following the expiry of the preceding period, submit an Annual Work Program and the related Budget for the first Calendar year or portion thereof in respect of the following exploration period.

5.2 If the Govemment wishes to propose any revisions or modifications to the Petroleum Operations specified in said Annual Work Program it shall, within thirty (30) days after receipt of that Program, so notify the Contractor, presenting all justifications deemed useful. In that event, the Government and the Contractor shall meet as soon as possible to consider the proposed revisions or modifications and to mutually establish the Annual Work Program and the related Budget in its final form, in accordance with good international petroleum industry 
practice. However, during the exploration period, the Annual Work Program and the related Budget for exploration established by the Contractor after the above-mentioned meeting shall be deemed to be approved provided that they comply with the obligations set forth in Article 4.

Each part of the Annual Work Program and Budget in respect of which the Government has not proposed any revision or modification within the period of thirty (30) days abovementioned, shall be carried out by the contractor within the stated time.

Should Government fail to notify the Contractor of its wish for revision or modification within the period of thirty (30) days above-mentioned, such Annual Work Program and the related Budget submitted by the Contractor shall be deemed to be approved by the Government.

5.3 It is agreed by the Government and the Contractor that knowledge acquired as and when the work proceeds or certain events may justify changes to the details of the Annual work Program. In that event, after notification to the Government, the Contractor may make such changes provided that the basic objectives of said Annual Work Program are not modified. ${ }^{12}$

Once annual work programs have been approved, many countries will also require that the IOC supply the HC with all the data derived from exploratory activities. Hence, in Colombia, an Association contract requires:

During the Exploration Period, the ASSOCIATION will deliver to ECOPETROL, as the information is obtained, all geological and geophysical information, edited magnetic tapes, processed seismic sections and all supporting field information, magnetic and gravimetric profiles, all in reproducible originals, copies of all geophysical reports and reproducible originals of all logs of wells drilled by the ASSOCIATION, including the final composite graph log for each well and copies of the final drilling report which includes the analyses of core samples, the results of the production tests and any other information related to the well, studies or interpretation of any nature carried out by the ASSOCIATION in the Contracted Area without limitation. ECOPETROL has the right at any time and by any process deemed necessary, to observe all of the operations and investigate the above mentioned information.

The purposes for requiring such information are straight-forward: the $\mathrm{HC}$ must have the requisite information to organize, on a macro level, the development of its oil and gas resources.

\section{Conclusion}

The final shape that a particular IPA takes will largely be a function of the bargaining position of the various parties, the level of knowledge about the Contract Area in question, and a multitude of other factors. Given that the final goal of both

12 Model Petroleum Production Sharing Contract between the Republic of Cote D'Ivoire and IOC, dated October 1993, taken from Seminar Materials from International Petroleum Agreements Conference held in Houston, Texas, 13-14 November 1997, produced by Gustavson Associate, Geologists and Engineers. 
parties to an IPA is to find a contract format that maximizes the chances for finding a commercial discovery, the preceding analysis has attempted to point out areas where the parties' interests coincide. To the degree that HCs and IOCs understand how the contractual structures outlined herein translate into work incentives and flexibility, the likelihood that a commercial discovery will result will be increased.

\section{FORCE MAJEURE}

\section{A. INTRODUCTION}

The expression "force majeure clause" describes a contractual term whereby one or both of the parties to a contract is excused from performance, in whole or in part, or entitled to suspend performance or to claim an extension of time for performance, upon the happening of a specified event or events beyond its control. ${ }^{13}$ Force majeure clauses generally begin with a provision excusing the obligations of the party claiming relief and then proceed to describe the events which constitute force majeure, frequently in great detail, but other times concisely.

The following analysis enumerates the requirements for force majeure, the events which trigger employment of force majeure clauses and the consequences of their use.

\section{B. REQUIREMENTS FOR FORCE MAJEURE}

Reliance upon a force majeure clause often requires fulfillment of one or more of the following conditions:

(1) the force majeure event is an impediment beyond the control of the claiming party;

(2) the event prevents or delays performance under the contract, in whole or in part;

(3) the event makes performance under the contract imprudent, substantially more difficult or substantially more expensive;

(4) the event was not due to fault or negligence of the claiming (or nonperforming) party; and

(5) the party claiming excused non-performance must have exercised reasonable diligence to overcome or remove the force majeure event.

Following are two examples of force majeure provisions:

13 Chitty on Contracts - General Principles, vol. 1, 27th ed. (London: Sweet \& Maxwell, 1994) at 704. 
If as a result of Force Majeure any Party is rendered unable, wholly or in part, to carry out its obligations under this Agreement, other than the obligation to pay any amounts due or to furnish security, then the obligations of the Party giving such notice, so far as and to the extent that the obligations are affected by such Force Majeure, shall be suspended during the continuance of any inability so caused and for such reasonable period thereafter as may be necessary for the Party to put itself in the same position that it occupied prior to the Force Majeure, but for no longer period. The Party claiming Force Majeure shall notify the other Parties of the Force Majeure within a reasonable time after the occurrence of the facts relied on and shall keep all Parties informed of all significant developments. Such notice shall give reasonably full particulars of the Force Majeure, and also estimate the period of time which the Party will probably require to remedy the Force Majeure. The affected Party shall use all reasonable diligence to remove or overcome the Force Majeure situation as quickly as possible in an economic manner, but shall not be obligated to settle any labor dispute except on terms acceptable to it and all such disputes shall be handled within the sole discretion of the affected Party.

No Party shall be considered in default of the performance of any of its obligations hereunder, if any failure to perform or any delay in performing its obligations under this Contract is prevented, hindered or delayed because of any event or combination of events which could not be foreseen and which was beyond the control of such Party, including without limitation natural and technical events."

\section{UNFORESEEABILITY AS A REQUIREMENT FOR FORCE MAJEURE}

Unforeseeability is also occasionally a requirement for reliance upon force majeure clauses. It may be argued that the non-performing party should not be entitled to rely on the clause where, at the time of making the contract, he could reasonably foresee events inevitably leading to its operation and could make provisions to facilitate completion of the contract. However, it has been suggested that force majeure clauses should not be limited to events or states of fact not in existence at the date of the contract or to those which are unpredictable at the time it was made. ${ }^{15}$ Requiring unforeseeability would unreasonably restrict the operation of force majeure clauses as the party seeking performance could almost always argue that an event was foreseeable. As a result, the other party to the contract would be required to perform when it is practically impossible to do so. Such a requirement could adversely affect war-torn or economically unstable countries where many, if not most, force majeure events would be foreseeable. For example, suppose rebels are active in the HC when the IPA is signed, and later disrupt the project and delay work. This could have been foreseeable but from the IOC point of view should clearly be an event of force majeure (unless perhaps the IOC was expressly required to provide military security against rebel activity). Companies would be reluctant to conduct business there knowing that they may be forced to perform a contract in the face of such adversity. 


\section{EVENTS Which TRIgGer IMPLEMENTATION OF ForCE MAJEURE}

The concept of force majeure is wider than that of "act of God" or "vis major" as the latter denotes events due to natural causes, without human intervention. On the other hand, force majeure events are not limited to those which occur in nature and can include:

(1) acts of war or insurrection, such as declared or undeclared war, civil war, uprising, guerilla activity, insurrection, riot, or any other hostile act, whether internal or external to the $\mathrm{HC}$;

(2) shortages or non-availability of materials, parts, fuel, labor, or transportation;

(3) labor disputes such as strikes, lockouts, sit-ins, or any other labor conflict;

(4) government action such as laws, rules, regulations or orders promulgated by any governmental body having, or claiming to have, jurisdiction over the parties or the operations hereunder; or

(5) government inaction such as failure or delay in granting visas, import licences, environmental and other government permits or authorizations required to perform the operations under the contract.

Since force majeure clauses by their nature are designed to protect against an unanticipated contingency, they cannot be limited to a precise definition or a finite list of examples. Consequently, if specific force majeure events are listed, the contract should make it clear that the list is being added by way of example and not by way of limitation.

Upon the occurrence of an enumerated event, the party relying on the clause must prove the occurrence of the event and that he has been prevented, hindered or delayed from performing the contract by reason of that event. Other occurrences which may also significantly affect the performance of a contract are not considered force majeure events. These include:

(1) weather conditions which are not extraordinary or where the contractor has specifically accepted weather risks;

(2) failure by a third party to provide adequate supplies required to complete the contract;

(3) lack of availability of equipment or problems associated with maintenance or mechanical breakdowns of contractor's equipment; or

(4) where the Contractor consists of a consortium of companies, there is often a provision that asserts that a force majeure circumstance applicable to one 
contractor party shall not relieve the remaining Contractor parties of their obligations.

\section{ECONOMIC FORCE MAJEURE}

Often, events of a purely economic nature, such as decreases in oil prices, are also characterized as non-force majeure. The fluctuation of economic conditions is a recognized unpredictability against which IOCs can protect themselves by assigning risk through the provisions of the relevant agreement. Therefore, even major changes in the economic climate should not justify judicial intervention as they could have been accounted for in the contract. It may also be argued that the doctrine of force majeure relieves a party of a contractual obligation only when a fortuitous event makes the performance impossible; thus, a decline in the market price of oil would not make performance 'impossible'; it would merely make the performance unprofitable. ${ }^{16}$

While the arguments against implementation of economic force majeure clauses are compelling, some courts have given effect to them where economic factors make performance more difficult. In Interpetrol Bermuda Ltd. v. Kaiser Aluminum International Corp., ${ }^{17}$ Trako Energy Corporation ("Trako") contracted to purchase heavy oil from Occidental Crude Sales Inc. ("Occidental Crude"). Trako also agreed to sell specified quantities of oil to Kaiser Aluminum International Corporation ("Kaiser"). Kaiser was to sell to Interpetrol the oil products purchased from Trako. As a result of a dramatic rise in the price of oil, Occidental Crude sought a release from the contract with Trako to take advantage of favourable market conditions. Trako permitted the release, allowing Occidental Crude to sell the oil to a third party for a higher price. As a result, Kaiser could not complete its contract with Interpetrol, and sought to invoke the force majeure clause excusing its failure to perform due to loss of oil supply. While Interpetrol claimed that the clause only excused unforeseeable, involuntary events, Justice Skopil for the Court of Appeal stated,

In a relatively free and fluid wholesale market, a seller should be entitled to utilize the power of his position to contract to his best advantage. That might include, as here, the extraction of a force majeure clause from a buyer. If the seller's supplier is not able because of market forces to require a similar provision in the agreement between seller and supplier, the result is that the seller is excused but the supplier is not."

The court excused Kaiser from performance under the clause.

In determining whether a party may rely on an economic force majeure clause, the courts will look to its construction. Contracting parties should specifically agree to include economic force majeure clauses if they wish the courts to excuse nonperformance resulting from economic conditions or constraints. If a contract's force 
majeure clause does not include a provision regarding economic fluctuations, it will be presumed that the parties intended to assign risk through the pricing mechanism contained in the agreement.

\section{EFFeCt Of DEClaRIng ForCE MAJEURE}

Most contracts require that the party claiming force majeure give notice to the other party. Generally, the contract will set forth specific time-frames by which notice must be given. In addition, most agreements call for some substantiation of the event and the causal connection to the inability to perform, including reasonably complete details of the event or occurrence.

Once force majeure has been declared, performance under the IPA is excused; however, the suspension of obligations shall apply only to the extent of the force majeure event. Obligations other than those affected by the force majeure event must continue to be performed in accordance with the IPA. For instance, payment of money otherwise due under the IPA is not excused by the occurrence of the force majeure event.

Upon the exercise of a force majeure clause, the obligations of the claiming party are suspended for so long as the force majeure event continues. Most clauses provide for an extension of the term of the contract, and allow for a reasonable period of time to resume operations and return operations to the same status as before the force majeure event. ${ }^{19}$ Other clauses include an option to terminate if the force majeure event exceeds a set length of time; discontinuance of the contract is possible upon giving some period of prior written notice.

\section{E. CONCLUSION}

Force majeure clauses can protect parties who would otherwise be required to perform contracts when circumstances render performance substantially more difficult or even impossible. However, the effectiveness of these clauses depends, to a large part, on their construction. When the terms of a contract are clear, the courts must give effect to the intentions of the parties expressed by the language they employ. Otherwise, force majeure clauses may be subject to the uncertainties concerning foreseeability and economic force majeure which are associated with the common law doctrine. Rather than leave the interpretation of their agreements to the courts, parties would be well advised to clearly and unequivocally state their wishes in the contract so they may adequately protect themselves against future contingencies. 


\section{Dispute Resolution}

\section{A. INTRODUCTION}

In the era of commercial globalization, international dispute resolution has taken on tremendous importance in business relations. The international petroleum industry has seen international arbitration become an integral aspect of agreements where foreign investment is involved. Thus, an understanding of the multitude of issues involved in international arbitration is essential to the contemporary practitioner involved in the negotiations of IPAs.

In this section of the article, the following fundamental aspects of international dispute resolution will be addressed:

(1) Understanding the various forms of dispute resolution that are available.

- Analyzing the differences in the mechanisms of dispute resolution, and in particular, the differences between the International Chamber of Commerce and the International Centre for the Settlement of Investment Disputes regimes.

- Paying tribute to the relationship between the international arbitration rules on the one hand, and the awards of the courts of various HCs on the other.

(2) Discussing the problem of sovereign immunity and how this can override the decisions of various international dispute resolution bodies.

(3) Contrasting administered and unadministered rules and the role of each on international dispute resolution.

\section{B. UNderstanding the VARIous Forms of Dispute Resolutions}

There are three dominant international arbitration institutions today. These are the the International Chamber of Commerce, International Centre for the Settlement of Investment Disputes and the London Court of International Arbitration.

\section{INTERNATIONAL CHAMBER OF COMMERCE ("ICC")}

Arbitration using the ICC guidelines is only possible if there is an agreement between the parties that provides for it. The ICC Rules are set in an international context and this allows a perception of neutrality to be attained by all of the parties in the dispute. Each year ICC arbitrations are held in some forty countries, in several languages, and with the involvement of arbitrators of some sixty nationalities 
representing all of the main legal systems of the world. ${ }^{20}$ Arbitration using the ICC Rules and the ICC court has become the leading international arbitration institution, both in terms of volume of cases and significance of disputes. ${ }^{21}$ Thus, the ICC is one type of international dispute resolution that negotiators of IPAs should always consider.

Under the ICC Rules, the parties usually stipulate the place of arbitration, the number of arbitrators, the manner in which they are selected, and the procedural and substantive law to be used. The ICC is well regarded because of the flexibility that it leaves to the potential parties of a dispute. However, there are a few controversial aspects of the ICC and these include the award process and the fees. Interestingly, the awards rendered by the ICC arbitrators cannot be directly communicated to the parties but they must be "scrutinized" and "approved" by the ICC court first. ${ }^{22}$ The potential for further delay here is not ideal. Some writers argue that having the administrative charges of both the ICC and the fees of the arbitrators calculated with reference to the dollar amount in dispute seems arbitrary. Nevertheless, it is this body that does most international arbitration work and that is selected as the most regular mechanism for international investment disputes.

The ICC recommends the following clause to parties who wish to be bound by the set of rules that it provides:

All disputes arising in connection with the present contract shall be finally settled under the Rules of Conciliation and Arbitration of the International Chamber of Commerce by one or more arbitrators appointed in accordance with the said Rules."

As previously mentioned, it is also desirable for parties to stipulate in the arbitration clause the law that is to govern the contract, the number of arbitrators and the place and language of the arbitration. Parties should obviously also ensure that the arbitration agreement is in writing.

\section{THE INTERNATIONAL CENTRE FOR SETTLEMENT OF INVESTMENT DISPUTES ("ICSID")}

The ICSID is the only public international organization to be created under a treaty. It is also important to distinguish this type of international arbitration from the others in that ICSID arbitration is only available in disputes in which a state, i.e., a national government, is a party. However, a state may designate one of its agencies as being sufficiently identified with the state as to qualify as "the state" for the purposes of the convention. $^{24}$ Also, the ICSID is different from the ICC, in that under the ICSID the

International Chamber of Commerce, "Rules of Arbitration of the International Chamber of Commerce" online: <www.iccwbo.org/htm/rulesenglish.htm> (Accessed 25 January 1998) [hereinafter ICC Rules].

J. Paulsson, "How Effective is Arbitration?" (Freshfields: Paris, 1997) at 1A-7.

Ibid. at 1A-8.

Intemational Chamber of Commerce, Arbitration/Dispule Resolution (The World Business Organization: 1996) at 1.

Supra note 22 at $1 A-9$. 
monitoring of the awards rendered requires the disappointed parties to ask the Chairman of the ICSID's Administrative Council to appoint a three member panel to review awards. ${ }^{25}$

The ICSID convention administers arbitration solely on the basis of the provisions of the court and the rules and regulations issued thereunder, excluding the application of any national arbitration law. The ICSID provides facilities for arbitration and conciliation in the dispute resolution process between contracting states and nationals of other contracting states. ICSID is designed to promote an atmosphere of mutual confidence between states and foreign investors with the goal of increasing the flow of private international investment. The ICSID convention contains a self-sufficient legal regime for a truly international form of arbitration. The only formal requirement is that consent must be in writing. The suggested model clause to invoke this form of international arbitration is as follows:

If, at any time during the duration of this contract or thereafter, there shall be a difference or dispute with respect to the construction, meaning or effect of this contract or arising out of this contract or concerning the rights and obligations hereunder ... either party shall have the right to refer the difference or dispute to the [ICSID conciliation/arbitration]. ${ }^{26}$

The ICSID convention has been a success in terms of its worldwide acceptance as over 100 states have ratified it. It should be noted that Canada has neither signed nor ratified the convention. This is very important because only parties who are nationals of signatory states may avail themselves of the ICSID mechanism. All HCs that have signed the ICSID convention are bound to recognize and enforce all ICSID awards to the same degree that they would enforce a final award rendered by their own courts. This applies to the signatory HCs that are not parties to the dispute as well. Thus, it could be unfair for a non-member to be involved in an agreement with a signatory member of the ICSID Convention because the member HC would not be able to enforce the award in the state of the non-member.

Because signatory states have only bound themselves to the same extent that they are bound to final court decisions, the awards rendered under ICSID are given no more authority than the national court in question. Thus, if the matter could not be enforced by the national court in question then the convention does not require that ICSID decisions fare any better. This creates a concem regarding sovereign immunity that will be discussed in more detail below.

There are also concerns about "immunity from execution" and "pre-award attachment."27 Van Den Berg notes that "Article 55 [of the ICSID convention] provides that nothing in Article 54 shall be construed as derogating from the law in

Liberia, Model Contract of March 1982 for Offshore \& Onshore Operations (Articles XXX1(A)), Petroleum Legislation, South and Central Africa, Suppl. 70-80.

27

A.J. Van Den Berg, "Recent Enforcement Problems under the New York and ICSID Conventions" (1989) 5 Arbitration International 2. 
force in any Contracting State relating to immunity of that State or any foreign State from execution."28 To address this issue, ICSID recommends the following model clause:

The [name of Contracting State] hereby irrevocably waives any claim to immunity in regard to any proceedings to enforce any arbitral award rendered by a Tribunal constituted pursuant to this Agreement, including, without limitation, immunity from service of process, immunity from jurisdiction of any court, and immunity of any of its property from execution. ${ }^{29}$

Van Den Berg notes that "attachment of the assets of the debtor before or during an arbitration can be important for a creditor to ensure future enforcement of the award if it is favourable to him or to enhance possible settlement of the dispute." ${ }^{30}$ For preaward attachment concerns, the arbitration rules suggest that the problem can now be solved only on the basis of a specific agreement of the parties authorizing pre-award attachment by a state court. Thus, parties should consider a clause such as the following:

The consent to arbitration recorded in [identify the basic clause] shall not preclude any party hereto from taking, or requesting any judicial or other authority to order, any provisional or conservatory measure, including attachment, prior to the institution of the proceeding or during the proceeding, for the preservation if its rights and interests."

Other clauses to be considered if choosing this mode of international arbitration include basic submission clauses such as consent in respect of both existing and future disputes. Also, special clauses that relate to the subject matter of the dispute may be required. These could include a stipulation that the transaction constitutes an investment, or a limitation of the subject matter of disputes that can be submitted to the ICSID centre. Other concerns may include special clauses that relate to the parties such as an agreement that a juridical person is under foreign control or a stipulation of the nationality of an investor. The method of constituting the tribunal and the applicable system of law should also be stipulated.

Article 26 of the convention provides that the consent of the parties to arbitration shall, unless otherwise stated, be deemed consent to such arbitration to the exclusion of any other remedy. Thus, an additional clause that may be considered when using the ICSID Rules is an agreement that other remedies are not excluded. Clauses to set the applicable rules of procedure, the place of proceedings and the division of costs are all important to include. Model clauses for all of the aforementioned clauses are also provided for in a recent article.

Ibid. at 14.

29 ICSID Model Clauses, Doc. ICSID 5/Rev., at cl. XIX, in 5 Asbitration International 14 (1989) and 12 Y.B. Com Arb. 183 (1987).

31 Allantic Triton Co. v. Republic of Guinea and Soguipeche, Cass. Com., 18 November 1986, in 5 Arbitration Intemational 19 (1989) and 12 Y.B. Com. Arb. 183 (1987). 


\section{a. The Additional Facility}

There is an avenue for the ICSID to administer certain proceedings between states and nationals of other states which fall outside the scope of the convention and this can be achieved through the Additional Facility of the ICSID convention. To use the Additional Facility, at least one of the parties must be a contracting state or a national of a contracting state. The arbitration rules followed by this body are based on the ICSID arbitration rules and also encompass some provisions derived from the convention and others from the UNCITRAL rules that are designed for disputes of a commercial nature. However, the awards granted under the Additional Facility are not enforceable under the convention. "With respect to arbitration proceedings, this means that awards, unlike awards rendered pursuant to the Convention, are not insulated from national law and that their recognition and enforcement will be governed by the law of the forum, including applicable international conventions." ${ }^{32}$

The ICSID and the ICSID Additional Facility do not themselves conduct the conciliation and arbitration between the parties. This is done by the arbitrators that are appointed by the parties or that are provided for in the convention. Recourse to conciliation and arbitration under the ICSID convention is completely voluntary; however, once the parties have consented to the process they are bound to follow it. ${ }^{33}$

\section{LONDON COURT OF INTERNATIONAL ARBITRATION ("LCIA")}

The arbitration rules of the LCIA were developed for use in any country throughout the world and under any system of law. The LCIA fulfils the role of ensuring the application of its rules or those of the UNCITRAL, and it alone is empowered to appoint arbitrators under the LCIA rules. The LCIA consists of a President, four vicepresidents and up to twenty-six other members to provide and maintain a proper balance of leading practitioners in the field of international commercial arbitration, drawn from the major trading areas of the world. The LCIA recognizes the increasing and proper role of alternative dispute resolution ("ADR"), and offers its services in the administration of conciliation and mediation, under institutional rules or under the UNCITRAL rules, or in assisting with ad hoc ADR, should the parties wish. ${ }^{34}$

A suggested model clause to invoke this mechanism of international arbitration is as follows:

The validity, construction and performance of this contract shall be governed by the law of England, and any dispute that may arise out of or in connection with this contract, including its validity, construction and performance, shall be determined by arbitration under the Rules of the London Court of Arbitration applicable to international arbitration at the date hereof, which Rules with respect to matters not regulated by them incorporate the UNCITRAL Arbitration Rules. The parties agree that 
service of any notices in reference such arbitration at their addresses as given in this contract (or as subsequently varied in writing by them) shall be valid and sufficient. 35

\section{SOVEREIGN IMMUNITY}

Under the ICSID convention, signatory states have only bound themselves to the same extent that they are bound to final national court decisions. In Article 55 of the convention, it is stated that the ICSID provisions and awards shall not override a country's sovereign immunity laws with regard to enforcement. "The doctrine of sovereign immunity is a principle of international law grounded on the assumption that sovereigns are equal and should not be subject to suit in the courts of another jurisdiction." ${ }^{36}$ Thus, the awards rendered under ICSID are given no more authority than the national court in question. If the contractual provision could not be enforced by the national court in question, then the convention does not provide that the decisions and awards rendered under ICSID will fare any better.

An example of sovereign immunity is provided in the case of S.T. Tringali Co. v. The Tug Pemex $X V .^{37}$ In that case, S.T. Tringali Co. brought a suit for damages against Pemex, a corporation owned by the government of Mexico. A writ of attachment was requested and issued in the United States and the S.S. Presidente Juarez, the property of Pemex, was seized to acquire jurisdiction and security in the suit. Pemex contended that the seizure of the S.S. Presidente Juarez was unauthorized because it was the property of a friendly sovereign power and thus was immune from seizure for security and satisfaction of judgment. The District Court of Texas agreed that the property of a friendly foreign government may be immune from execution such as its credits in banks and the like, however, it held that the vessels of Pemex were not considered as being owned by the Republic of Mexico, but instead, by an independent corporation engaged in a private commercial activity. Therefore, the respondent's request that the seizure of the S.S. Presidente Juarez be quashed was denied.

Smith et al..$^{38}$ note that in Tringali, the court utilizes the "restrictive theory" of sovereign immunity. Different countries have developed statutes that codify this practice of limited immunity for sovereigns in their courts. Canada's legislation is entitled the State Immunity Act. $^{39}$

An interesting case that deals with the United States Foreign Sovereign Immunities $A c t^{30}$ is that of Carey v. National Oil Corporation." In Carey, the appellant was New England Petroleum Corporation ("NEPCO") which is a New York company. NEPCO was a seller of residual fuel oil in the eastern United States, and one of the

E. Smith, et al., International Petroleum Transactions (Denver: Rocky Mountain Mineral Law Foundation, 1993) at 60.

Ibid. at 100.

274 F. Supp. 227 (S.D. Tex. 1967) [hereinafter Tringali].

Supra note 35 at 33.

R.S.C. 1985 , c. S-18.

28 U.S.C. $\$ 1602$ et se. (1988).

592 F.2d 673 (2d Cir. 1979) [hereinafter Carey]. 
outlets from which NEPCO obtained its oil from was a refinery located in the Bahamas called PETCO.

PETCO was a wholly owned subsidiary of NEPCO. The appellant, Carey, was an assignee of PETCO. In 1968 PETCO entered into a long term contract to purchase crude oil from Chevron Oil Trading ("COT"). In September 1973, the govermment of Libya nationalized several foreign-owned oil concessions in that country, including that of a company with which COT was affiliated. Thereafter, COT suspended all crude oil deliveries to PETCO and terminated its contract with PETCO. In order to obtain the oil that PETCO needed, it entered into a subsequent contract with the National Oil Corporation ("NOC"), which was a company wholly owned by the Libyan government. This new contract was at a substantially higher price than the canceled one with COT. Within a month, Libya imposed an embargo on oil exports to the United States, the Netherlands and the Bahamas. Thus, NOC canceled its contracts with PETCO. PETCO was then forced to enter into a new contract with NOC for crude oil that was to be refined in Italy during the embargo and then in the Bahamas after the embargo was lifted. In January 1974, a contract was executed which called for a price per barrel more than three times what PETCO had been paying previously. The suit was an attempt to recover damage for NOC's failure to deliver oil under the 1973 contract, for breaches in the 1974 contract, and for overcharges on the charter parties. The damages sought totaled approximately $\$ 1.6$ billion.

In applying the Foreign Sovereign Immunities Act it was held that NOC is considered a foreign state under s. 1603(a) and (b)(2) since NOC is a corporation in which "a majority of whose shares or other ownership interest is owned by a foreign state or political subdivision thereof." 42 In addition, the United States Supreme Court has held that the Foreign Sovereign Immunities Act is the exclusive basis for jurisdiction over a foreign sovereign in the federal courts. ${ }^{43}$ In 1990, Congress amended the Foreign Sovereign Immunities Act to include the following:

Section 1605. General Exceptions to the Jurisdictional Immunity of a Foreign State.

(a.) A foreign state shall not be immune from the jurisdiction of the courts of the United States or the States in any case

in which the action is brought either to enforce an agreement made by the foreign State with or for the benefit of a private party to submit to arbitration all or any differences which have arisen or which may arise between the parties with respect to a defined legal relationship, whether contractual or not, concerning a subject matter capable of settlement by arbitration under the laws of the United States, or to confirm an award made pursuant to such an agreement to arbitrate, if (a) the arbitration takes place or is intended to take place in the United States; (b) the agreement or award is or may be govemed by a treaty or other international agreement in force for the United States calling for the recognition and enforcement 
of arbitral awards; (c) the underlying claim, save for the agreement to arbitrate, could have been brought in a United States court under this section or section 1607, or; (d) paragraph one of this subsection is otherwise applicable."

In the United States, there is now legislation that prevents a party to an ICSID arbitration agreement from claiming sovereign immunity. Thus, if the case of Tringali was to come before the United States courts today, the sovereign immunity argument used by Pemex would no longer be available if Pemex and S.T. Tringali Co. had agreed to use arbitration to settle the dispute and the arbitrator(s) decided against Pemex. This same type of legislation does not exist in Canada or many other countries. In Canada, the State Immunity Act has the following provision:

4 (1) A foreign state is not immune from the jurisdiction of a court if the state waives the immunity conferred by subsection 3(1) by submitting to the jurisdiction of the court in accordance with subsection (2) or (4). 45

ICSID recommends the model clause referred to above to deal with this concem. ${ }^{46}$ Thus, this problem appears to be soluble with careful drafting.

\section{CONTRASTING ADMINISTEREd AND UNADMINISTEREd RULES}

Another very important issue to be addressed is whether the parties would prefer a system of arbitration that is governed by administered or unadministered rules. Administered arbitration is also known as institutional arbitration, whereas unadministered arbitration is associated with ad hoc methods of arbitration. The three aforementioned modes of international arbitration (ICC, ICSID, and LCIA) all involve administered rules. With unadministered arbitration, the parties must be sure to include in their agreement all substantial and procedural issues that may arise. This is problematic in that future concerns cannot always be predicted, and if not included in the agreement, one or more of the parties could be severely disadvantaged. Also, with international agreements, no ad hoc agreement has the same force in other jurisdictions such as the ICSID agreement does.

Other differences between administered and unadministered rules are those dealing with appeals, fees and the potential for delays. The ad hoc route avoids paying administrative fees that come with administered arbitration. Also, while the parties have greater control over the process via the ad hoc method of arbitration, this can be problematic in that there can develop more delays in the arbitration process. There is the potential for additional delay arising out of scheduling conflicts between the various arbitrators and parties. Also, there is no other person or body to complain to when using ad hoc arbitration. However, this potential issue could be dealt with by including in the ad hoc agreement a person or body for this purpose. 


\section{E. Conclusion}

When an $\mathrm{HC}$ is a party to a dispute, there are strong reasons to prefer a well-drafted ICSID agreement over all of the other modes of international arbitration. However, because Canada is not a member of ICSID, this altemative is not available to a Canadian party. The support of Alberta, Ontario and Quebec is needed before Canada can become a member. ICSID appears to be a significant improvement over ad hoc methods of arbitration. It is important to note that an ICSID award is treated as a debt on the part of the owing party to the World Bank, thus it can get paid very quickly. ICSID awards are also upheld in all of the countries that are ratified members and this creates a further advantage for the successful party in the arbitration.

There are some troublesome areas in the ICSID convention and included in these is a concern with regard to sovereign immunity. This potential pitfall can be overcome by including a clause such as the model provided above.

In Canada, the ICC is probably the best international avenue that both the state and other Canadian parties have. The ICC is well developed and it is more flexible than the LCIA in that it allows the parties to select the arbitrator(s). However, the ICC has some shortcomings and the drafter of an international dispute resolution clause must be careful to address the issues discussed above.

An unadministered mechanism of dispute resolution can be appropriate when the provisions are drafted very carefully. However, the drafter must be sure to include all potentially relevant issues because failure to do so could be costly. Drafting requires a thorough practitioner with a comprehensive checklist for this choice of arbitration. 